\title{
BEHAVIORAL FINANCE: HOUSEHOLD INVESTMENT AND BORROWING DECISIONS
}

\author{
Pavlo Illiashenko \\ Tallinn University of Technology, School of Business and Governance \\ Email: pailli@ttu.ee
}

\begin{abstract}
Behavioral finance is still mostly perceived as a field solely devoted to the study of asset pricing and the behavior of individual investors. Such interpretation is largely misleading as it overlooks a growing body of empirical work in household finance, a sub-field of behavioral finance concerned with household investment and borrowing decisions. By focusing on household under-saving, non-participation, and under-diversification, as well as mistakes in choosing debt contracts and managing debt obligations, this paper aims to present recent findings from the field of household finance to a wide audience. This review differs from existing ones by focusing on the plurality of non-mutually-exclusive explanations of observed phenomena, including explanations from both behavioral and neoclassical traditions. In addition, this paper focuses on the choice between fixed-rate and adjustable-rate mortgages given their significance for macrofinancial stability and discusses evidence of firms being aware of the behavioral weaknesses of households and exploiting them readily.
\end{abstract}

\section{JEL Codes: D10, D14, G11, G21, G40}

Keywords: behavioral finance, household finance, household saving, investment decisions, household debt, consumer credit, mortgages

\section{INTRODUCTION}

Behavioral finance has established itself as a complex web of related sub-fields of research with no single definition and poorly defined boundaries, but which aims to understand the financial decisions of economic agents. However, the public still perceives the field as being mostly devoted to the study of asset pricing and the behavior of individual investors.

This framing, however useful, overlooks a growing body of empirical work focused on household and corporate financial choices, that is household finance and behavioral corporate finance. ${ }^{1}$

Ten years on from the global financial crisis, this perception seems especially counterproductive as household finance has the potential to explain the demand-side factors that led to the crisis and that made the post-crisis economic recovery painful for many countries.

Since its original formulation by Campbell (2006), household finance has been defined as a field of study largely focused on the mistakes households make when using financial markets to achieve their objectives. Given that focus, it is hardly surprising that, compared with other sub-fields of behavioral finance, household finance has made the most progress in the decade since the global financial crisis.

The crisis not only made the financial mistakes of households clear and relevant, it also contributed to the increasing availability of relevant data. First, the events of 2007-2009 drew attention to the many empirical observations that were difficult or impossible to reconcile with standard theories. Then, in response to perceived market failures, policymakers implemented policies to protect consumers and regulate lenders, providing scholars with natural experiments to study the impact of those policies. In turn, the need to evaluate policy and the general recognition of the importance of detailed data on household

${ }^{1}$ Behavioral finance can be viewed as a combination of micro behavioral finance and macro behavioral finance, echoing the distinction of micro- and macroeconomics. The former is the study of financial decisions made by households and firms at the micro level, examined from a behavioral perspective. The latter is the study of the macroeconomic consequences of those decisions. 
financial choices resulted in an increased quality and availability of administrative and propriety datasets (including household surveys that had typically been administered by central banks). ${ }^{2}$

While the global financial crisis showed that individual financial decisions are very important for both individuals and for aggregate outcomes, the importance and relevance of household finance as a field of study is not solely the result of the crisis. Household finance focuses not only on expanding the set of possibilities available to households (due to financial liberalization) but also considers the challenges that have risen in recent decades (Calvet et al., 2015).

At least three sets of challenges are prevalent.

First, while the demographic transition has contributed to the increased uncertainty over the government-sponsored pension schemes (mostly due to the higher future dependency ratios), the shift from defined benefits to defined contribution retirement saving plans shifted financial risk from companies to households. Additionally, low interest rates and the projected low rate of economic growth complicated the task of saving for retirement.

Secondly, in recent decades (and in the most recent decade for many developing countries), the level of household debt has risen dramatically, ${ }^{3}$ not least because of lower disposable income growth and reduced savings rates. Together with the increased responsibility of saving for retirement, this makes households more vulnerable to economic shocks.

Finally, as suggested by Campbell (2006), many investment products allow some cross-subsidization from naive to sophisticated households, which, according to Campbell, means that household financial mistakes may inhibit financial innovation. However, even more importantly, costly financial mistakes lead to a high dispersion in investment returns between sophisticated and nonsophisticated investors, which worsens the inequality of wealth distribution. In-line with this suggestion, Lusardi et al. (2017a) demonstrated that up to $40 \%$ of U.S. wealth inequality could be attributed to that difference in financial knowledge.

While household finance is as relevant and important as ever, the field is still relatively unknown to a wide academic audience. This unfortunate fact at least partially follows from the field's high fragmentation and its increasing specialization, which is characteristic to behavioral finance in general. Even a brief familiarization with literature makes it evident that researchers working in the same field rarely read each other's work simply because they subscribe to a slightly different tradition. As a result, the field of household finance has the potential to benefit from the integration of existing knowledge, which may also decrease the probability of policy decisions driven by ideology.

Given the above, reviewing the literature on household finance in 2017 is sensible, especially since the challenges facing households have become even more apparent in recent years as governments and regulators have shifted to a proactive stance on many financial issues.

There is a large body of excellent literature on the topic to review, including classics like Campbell (2006) and Tufano (2009), and more recent papers from Guiso and Sodini (2013) and Agarwal et al. (2017). This review, however, is different in several important ways.

First, the paper attempts to combine the more theoretical approach (focus on normative models) from Campbell (2006) and Guiso and Sodini (2013) with the more empirical approach (cataloging empirical phenomena) of Tufano (2009) and Agarwal et al. (2017). In doing so, this review acknowledges the existing differences in the state of research in different subfields of household finance and explores household investment and borrowing decisions slightly differently.

Secondly, this review relies on the most recent findings, mostly working papers. While I have immense respect for the peerreview process, the highly dynamic nature of the field makes it impossible to consider only the works already published in peer-reviewed journals and still review new research. In this respect, I follow John Cochrane when he says: "any work relying only on published research is hopelessly out of date."4

Thirdly, in contrast to previous literature, this paper gives more space to the review of findings related to rent extraction, the act by businesses of exploiting households' mistakes. Since the evidence shows that businesses are aware of households' behavioral weaknesses and are eager to exploit them, any attempt to address those mistakes should be placed in a realistic context; in this case, that means to explore the topic of rent extraction.

\footnotetext{
${ }^{2}$ The lack of detailed data may explain why the study of household finance arrived on the scene more than a decade after behavioral finance established itself as a legitimate and respected field of study (Campbell, 2006). However, it is also worth noting that household finance was largely excluded from the field of financial economics until recently, as this field has traditionally been organized into asset pricing and corporate finance, with contributions in household finance typically classified within the field of asset pricing (Guiso and Sodini, 2013). Tufano (2009) suggests this fact may be explained by a century-old intellectual and cultural approach that separated household and business topics by gender and geography. In this framework, household finance was meant to be a part of home economics (consumer science) which is still largely separated from mainstream economics.

${ }^{3}$ The high level of indebtedness is not an exclusively a distant problem. According to Lusardi et al. (2017b), recent cohorts of potential retirees have taken on more debt and face greater financial insecurity than do their older peers.

${ }^{4}$ https://johnhcochrane.blogspot.com.ee/2017/09/a-paper-and-publishing.html
} 
Finally, and most importantly, the paper relies on the assumption that the framing effect is important not only for day-to-day decisions (as behavioral economics suggests) but also for the way scholars and laypeople perceive academic literature. While this review assumes that its readers may possess a limited knowledge of the field, and therefore covers the basics, the central focus of the paper is the plurality of non-mutually-exclusive explanations of the observed phenomena. In other words, while the presented findings are not new, the way they are presented (the framing effect in action) may result in new knowledge and help avoid the negative consequences of fragmentization.

Therefore, to avoid reinforcing a naive dichotomy between behavioral and classical finance, this paper makes virtually no distinction between "rational" (i.e., originated within the framework of standard finance) and "behavioral" explanations (which are more likely to originate within the framework of behavioral finance). Instead, the discussion of possible explanations for phenomena related to investment and borrowing is divided into three categories: constraints, non-standard preferences, and (biased) beliefs.

The first category is comprised of financial (usually referred to as fixed costs in investment decisions and financial or liquidity constraints in borrowing decisions) and cognitive constraints. The latter group may be understood as high opportunity costs of time and effort that should be allocated to gathering and processing information, as well as to making a decision. In the behavioral tradition, inattention and inertia are examples of constraints, while in the classical finance tradition, the presence of cognitive constraints is usually identified by the importance of financial literacy and sophistication. Indeed, if less financially literate individuals make sub-optimal financial decisions, it means that they are constrained by a lack of relevant knowledge or training.

The second category includes explanations based on a broad understanding of non-standard preferences, including: (1) time inconsistency, present bias, and limited self-control; (2) social preferences and susceptibility to peer pressure and preference for social status; (3) time-varying risk aversion, mostly in the sense that household risk preferences depend on personal experience; (4) preference for the familiar; and (5) identity considerations.

The third category explains important phenomena in household finance with the help of beliefs and behavioral biases. Because it is not always obvious if a belief is "rational" or "biased", the paper refers to this category as "(biased) beliefs", implying that most but not all explanations in this group are related to the notion of behavioral biases.

As the goal of this approach is to show the diversity of competing but non-mutually-exclusive explanations for as many issues as possible, this paper chooses width over depth. Instead of reviewing the specific and well-defined area of household finance, this review attempts to cover as many different but related topics as possible. In other words, the motto of the paper is "a little bit about everything" rather than "everything about something."

The rest of the paper is structured as follows: first, the paper reviews the major findings in household finance that deal with the asset side of households' balance sheets (decisions related to savings, stock market participation, and portfolio diversification). The following section focuses on the liabilities side of households' balance sheets (decisions related to the choice of debt contracts, especially on the choice between fixed-rate and adjustable-rate mortgages, as well as on the management of debt obligations). Finally, each section concludes with a review of the evidence of rent extraction, or the ability of the corporate sector to exploit households' behavioral biases.

\section{HOUSEHOLD FINANCE: ASSETS}

An extensive body of literature suggests households tend to make costly mistakes when managing financial assets. A series of early papers found that individual investors suffer trading losses even before fees ${ }^{5}$ (Barber and Odean, 2000; Grinblatt and Keloharju, 2000), possibly explained by behavioral biases like overconfidence, the disposition effect, limited attention, and under-diversification (Barber and Odean, 2013). More recently, Weber et al. (2014) estimated that under-diversification and preference for lottery stocks ${ }^{6}$ are the most harmful among those mistakes and cost individuals $4 \%$ and $3 \%$ of annual performance, respectively.

While the narrow research agenda of "bias searching" continues, the focus of current research has shifted to the determinants of investment decisions in the context of households' total wealth.

First, researchers have expanded the scope of analysis by looking beyond active stock market trading. While studies of detailed micro data to understand investments in real assets are scarce, ${ }^{7}$ there is an increasing amount of literature that

\footnotetext{
${ }^{5}$ The average hides a high heterogeneity in trading performance. There is evidence that a minority of investors earn positive risk-adjusted returns (Barber et al., 2014).

${ }^{6}$ Stocks (or financial assets in general) with low-probability large-gain returns.

${ }^{7}$ In an interesting study, Brunetti and Torricelli (2016) found that 16\% of Italian second homes are not rented (the share varies from $10 \%$ in 2004 and $15 \%$ in 2002 and 2006 to $21 \%$ in 2012). While this fraction may not seem particularly large, unrented second homes in that sample could generate additional annual revenue of approximately EUR 4,000, which is just $20 \%$ less than the yield of the rented second homes to their owners. That would seem to indicate that either households' motives for purchasing a second home go beyond profit-seeking or (more likely) that households suffer from inertia and experience high cognitive costs of action.
} 
analyzes investments in risky financial securities in the context of total household wealth (variations of the famous Swedish dataset used by Calvet and coauthors, for example, Calvet et al., 2007).

Secondly, there are efforts to discover new factors that influence investment choices. For example, some recent findings indicate that risk aversion is affected by past stock market performance (Cordes et al., 2017); the difference in framing between changes in asset price levels and asset returns influences investors' expectations of future returns (Glaser et al., 2016); informationally irrelevant paths of asset price developments shape investors' behavior and satisfaction with the investment experience (Nolte and Schneider, 2016; Grosshans and Zeisberger, 2017).

The rest of this section reviews empirical evidence related to household investment decisions, aiming to both describe and explain the actions of households. More specifically, the section presents evidence that, contrary to the predictions of standard theories, households generally fail to save for retirement, allocate an adequate share of their wealth to risky assets, and diversify their financial portfolios. The final subsection presents evidence of rent extraction related to household investment decisions.

By focusing on the failures to save, allocate, and diversify (i.e. under-saving, non-participation, and under-diversification), the paper inevitably omits several research topics. Some of these are well-researched but less important to policymakers and macroeconomists (e.g., the behavior of individual investors), while others are very important but not well-researched (e.g., investments in human capital).

\subsection{Under-saving}

Academics and policy makers alike believe households do not save enough for retirement and for rainy-day situations. However, there is little empirical evidence to support that claim, at least at the global level. ${ }^{8}$ This is partially because detailed micro data is lacking and because it is difficult to assess the optimal level of private savings.

Furthermore, while many estimates suggest most countries will face a full-scale pension crisis in the future, those estimates are sensitive to the underlying assumptions and generally point to a problem at the government level and not the individual level. For instance, the WEF (2017) projects the global retirement savings gap will reach USD 400 trillion by 2050 . However, only $24 \%$ of that gap will be driven by insufficient private savings; $75 \%$ will be driven by unfunded government pension promises, with the remaining $1 \%$ driven by unfunded corporate pension plans.

On the other hand, personal data from the United States clearly confirms that under-saving is a severe and widespread phenomenon. Munnell et al. (2012) estimated that the proportion of working Americans that will face difficulties in maintaining their lifestyle during retirement due to insufficient savings has increased from about $30 \%$ at the beginning of the 1980 s to over $50 \%$ as of 2010 . Then, using a survey of consumer finances, Rhee and Boivie (2015) showed that $45 \%$ of U.S. working-age households have no retirement savings and most strikingly, about half of those households are between the ages of 45 and 65 . Lastly, a 2016 report on the economic well-being of U.S. households documented that $46 \%$ of adults say "they either could not cover an emergency expense costing $\$ 400$ or would cover it by selling something or borrowing money" (Larrimore et al., 2016). The latter indicates that the problem of under-saving goes well beyond retirement savings and that households also struggle to accumulate financial buffers to protect themselves in the event of an emergency.

Finally, there is growing evidence that even when households do save for retirement, they may do it inefficiently. In addition to investment mistakes, individuals also fail to invest in corporate retirement plans that match an employee's contribution even if they can make penalty-free withdrawals, basically rejecting free money (Choi et al., 2011, among others).

The potential adverse consequences of under-saving are enormous for individuals and governments, which entices governments to enforce policies aimed at boosting saving rates. However, somewhat surprisingly from the point of view of classical theories, empirical findings show that neither interest rates nor tax incentives have a significant influence on decisions to save. For instance, the analysis by Chetty et al. (2014) of 41 million observations of savings for the population of Denmark found that one dollar of government spending on subsidies increases total savings only by $1 \%$. At the same time, behavioral policies that raise retirement contributions if individuals take no action (such as automatic employer contributions to retirement accounts) substantially increase wealth accumulation.

\section{Constraints}

Since most households in developed countries have access to some financial services, the constraint in the form of transactional and direct fixed costs is unlikely to explain the failure to save. However, this might not be true for poorer individuals. For instance, a study in less developed countries found that transactional and pecuniary (monetary) costs constrain households' ability to save (Karlan et al., 2014). 
Among cognitive constraints, the literature highlights the importance of inertia and inattention (Goda et al., 2015). For instance, in a series of field experiments in the Philippines, Karlan et al. (2016) demonstrated that simple reminders have the potential to increase savings.

Finally, a large body of literature shows that a low level of financial literacy is causally associated with poor retirement planning and under-saving (Lusardi and Mitchell, 2014).

\section{Non-standard preferences}

Saving requires the sacrifice (delay) of an immediate reward to obtain a greater reward in the future. Thus, it is not surprising that empirical evidence confirms that individuals with a present bias (those with inconsistent time preferences and who place a greater emphasis on the present than the future) are more likely to under-save (Goda et al., 2015).

One of the most recent streams of research in this area concerns the effect of peer pressure. Kast et al. (2012) tested the effectiveness of self-help peer groups as a commitment device for savings through randomized field experiments among Chilean micro-entrepreneurs and found that these groups indeed serve as a powerful tool to increase savings. This line of research demonstrates two important points. First, a large and growing body of literature documents that households show substantial demand for commitment devices, demonstrating that they acknowledge the presence of self-control problems (it is usually assumed that limited self-control follows from present bias). Secondly, the effectiveness of peer pressure suggests the presence of social preferences, as individuals are influenced by their peers.

\section{(Biased) beliefs}

Several studies concluded that exponential growth bias (the tendency to underestimate the effects of compound interest) affects a wide range of financial decisions, including the decision to save (Stango and Zinman, 2009a; Goda et al., 2015; Levy and Tasoff, 2016).

Interestingly, empirical evidence shows that both excessively high and excessively low levels of optimism negatively affect saving decisions. While Puri and Robinson (2007) concluded that more optimistic people are more likely to save, optimism about the future reduces the probability of joining a pension scheme (Balasuriya et al., 2014). At the same time, Perry and Morris (2005) documented that individuals who are pessimistic about their level of control over outcomes are less likely to save.

\subsection{Non-participation}

Standard finance theory states that all households, no matter how risk-averse, should hold some risky assets in their financial portfolios to take advantage of the equity premium (as long as it is positive). However, one of the oldest puzzles in household finance (pioneered by Haliassos and Bertaut, 1995) states that a substantial proportion of households does not invest in risky financial assets. Interestingly, limited participation (the participation puzzle) is a broad phenomenon that extends beyond investments as many households do not hold debt and do not participate in insurance markets (Guiso and Sodini, 2013).

Over the years, scholars have proposed theories to explain non-participation. The theories emphasize the role of participation costs, non-standard preferences, the heterogeneity of beliefs, and the importance of trust and personal experience. While it is useful to review some of the theories, it is worth keeping in mind that most of them are not mutually exclusive and individually are likely to explain only a small part of the phenomenon. Indeed, Kaustia and Luotonen (2016) analyzed the role of institutional, traditional, and behavioral factors in the context of 19 European countries over 2004-2013 and concluded that the relevant variables from existing literature explain only $30 \%$ of the variation in the participation decision.

\section{Constraints}

Households may fail to invest in the stock market because they face fixed costs of participation like monetary expenses (to set up and maintain an investment account), information costs ${ }^{9}$ (learning about financial products), and simple alternative costs of devoting their time to investment decisions (Vissing-Jorgensen, 2003). This theory can explain some stylized facts (e.g., higher participation among wealthy and more sophisticated individuals). However, it fails to explain why the participation rate among the wealthy (while still higher than among poor individuals) is still rather low, as well as the cross-country variation in stock market participation (Briggs et al., 2015).

Finally, given the high heterogeneity of participation at the individual level, the concept of fixed costs of participation in isolation serves as a residual, which represents all unexplained variation. In other words, it is important to understand the individual difference in fixed costs of participation which remains large when controlling for the standard set of sociodemographic variables. 


\section{Non-standard preferences}

One of the most important recent streams of literature relates personal economic experiences to financial decisions directly or through individuals' preferences, such as risk attitudes.

For instance, Malmendier and Nagel (2011) and Andersen et al. (2016) showed that living through traumatic macroeconomic experiences has a negative impact on risk-taking behavior and is negatively associated with the proportion of risky assets in households' financial portfolios. Similar studies found that exposure to financial and corporate fraud causes a lower level of stock market participation (Gurun et al., 2015; Giannetti and Wang, 2016).

At the same time, exposure to a positive experience leads to the opposite effect. For example, Kaustia and Knüpfer (2008) documented a strong positive link between past IPO returns and future subscriptions at the individual level among Finnish investors.

Finally, the lack of preference for sensation-seeking (Grinblatt and Keloharju, 2009 showed that sensation-seeking is associated with higher trading activity) or identity considerations may also make households less likely to invest in risky securities (see Akerlof and Kranton, 2010 for a discussion of the role of identity in economic decisions).

\section{(Biased) beliefs}

To invest in equities, one should be convinced that the stock market yields an expected return in excess of the risk-free rate. Thus, the subjective beliefs of individuals may influence their decision to participate.

Favoring this explanation, Hurd et al. (2011) and Kezdi and Willis (2009) found that people with more optimistic beliefs about stock returns are more likely to invest via the stock market. ${ }^{10}$

Political beliefs (which can be viewed as non-standard preferences related to identity considerations) may also affect participation decisions. For instance, Kaustia and Torstila (2011) documented that left-wing voters and politicians in Finland are less likely to invest in stocks.

In addition, Guiso et al. (2008) showed that households that are reluctant to trust others are less likely to own stocks. They argue that many individuals may perceive the stock market as a type of swindling street game. Even after observing many rounds (a history of positive returns in the market), households may not trust the fairness of the game. According to this interpretation, households fail to learn from the history of past returns and as a result fail to invest in risky securities. Therefore, non-participation can be understood as an investment mistake that results from biased learning.

\subsection{Under-diversification}

Household portfolio returns are influenced by the overall level of risk taken and by the efficiency of diversification. An underdiversified portfolio has a higher risk because it contains an uncompensated idiosyncratic risk (idiosyncratic risk increases the volatility of the portfolio without improving its expected return). To hold only systematic risk and, thus, maximize the Sharpe ratio, households must be fully diversified and hold the market portfolio.

However, empirical evidence shows that households are under-diversified and are far from holding the market portfolio. Studies starting from Van Horne et al. (1975) consistently show that among U.S. households that directly own public equities, the median number of stocks held is in the range from two to three (Polkovnichenko, 2005). Due to under-diversification, investors hold inefficient portfolios. Goetzmann and Kumar (2008) found that $86 \%$ of portfolios in their sample (data as of 1996) are below the capital market line, while Weber et al. (2014) found almost the same result (80\%) for a sample of German portfolios for the period 2003-2012.

Importantly, the effect of under-diversification does not disappear if we consider that households own equities indirectly, through mutual funds or retirement accounts. While the proportion of wealth invested directly in stocks is small as shown by Anderson (2013), Calvet et al. (2007) showed that many households in Sweden still expose themselves to a high level of uncompensated idiosyncratic risk in the context of total financial wealth (i.e., considering all risky investments).

Some scholars suggest that households hold under-diversified portfolios deliberately as a hedge. According to this view, individuals may rationally avoid certain securities or whole segments of the stock market if they believe the returns on those securities are correlated with their labor income (Calvet et al., 2004; Davis and Willen, 2013). In other words, since wages and stock market returns are correlated at the industry level, income hedging requires that households invest in sectors other than those in which they work (Guiso and Sodini, 2013). However, we observe the opposite: individuals overwhelmingly invest in the stocks of their employers (Benartzi, 2001; Massa and Simonov, 2006) and suffer adverse financial consequences because of those actions (Lee et al., 2008).

${ }^{10}$ Bailey et al. (2017) provide a similar result for the case of investments in residential real estate. Using data on social interactions, they found that individuals whose Facebook friends experienced large gains in house prices were more optimistic about real estate investments and would be more likely to invest in the housing market. 


\section{Constraints}

While transactional and pecuniary costs may at least partially explain non-participation, it is hard to argue that these financial constraints negatively affect the decision to diversify. If households have enough financial resources to form a portfolio of risky assets, they almost by definition have access to cheap mutual funds that invest passively in a broad stock market index. In this case, by holding just one type of risky security (e.g. SPDR S\&P 500 ETF Trust) households can hold well-diversified portfolios.

At the same time, cognitive constraints can be expected to play at least a partial role in explaining non-participation. Empirical evidence confirms that notion, as more sophisticated individuals are shown to have better-diversified portfolios, also in the context of total financial wealth (e.g., Anderson, 2013).

\section{Non-standard preferences}

Theories of under-diversification based on non-standard preferences argue that households prefer certain financial assets regardless of their returns. Huberman (2001) argues that investors have a taste for familiar assets regardless of their ability to profit from such investments.

Another theory suggests that households concerned with their social status may rationally decide to hold idiosyncratic risk and, hence, under-diversify. These households hope to earn abnormal returns from their overall riskier portfolio and to increase their chances of "getting ahead of the Joneses," to achieve higher returns than their peers (Roussanov, 2010).

\section{(Biased) beliefs}

Under-diversification might be justified if households have superior information about stocks either because of geographical proximity or because of time invested in learning about companies. Massa and Simonov (2006) explained the anti-hedging behavior of Swedish households by suggesting they have superior information about the industries in which they are employed. Similarly, Van Nieuwerburgh and Veldkamp (2010) showed that investors may rationally choose to specialize in assets in which they have a prior informational advantage.

However, against this backdrop, empirical studies with only a few exceptions (e.g., Bernile et al., 2015) show that households do not earn positive abnormal returns based on their supposedly superior information (Seasholes and Zhu, 2010; Doskeland and Hvide, 2011). The only way to interpret this evidence is to suggest that if households under-diversify because they believe in their informational advantage, they make a financial mistake, possibly because of overconfidence. ${ }^{11}$

\subsection{Rent extraction}

In principle, households should be able to reduce the detriment of their investment mistakes by allocating financial resources to a more passive investment approach (investing via mutual funds) or by relying on professional financial advice. However, empirical studies suggest there are critical challenges to obtaining positive results from that type of approach.

Disregarding the possibility that professional money managers may be susceptible to behavior biases, there is substantial evidence of rent extraction via high mutual fund costs. In an important paper, Barber et al. (2005) demonstrated that while investors became sensitive to visible front-end-load fees over the years, they nonetheless remained less attentive to less visible costs such as operating expenses. The authors also concluded that this fact is known in the mutual fund industry and is used to take advantage of investors. This results in a situation in which mutual funds with higher fees perform worse than competitors, but still attract more clients in terms of money flows.

While Barber et al. (2005) provided evidence that advertisements do work for the mutual funds industry, Cooper et al. (2005) pointed to the success of another kind of marketing strategy. They presented evidence that mutual funds change their names to take advantage of popular investment styles which in their sample resulted in an average cumulative abnormal money flow of about $30 \%$.

Beyond the problem of high fees, some mutual funds attempt to artificially inflate returns by "juicing" (Harris et al., 2015). "Juicing" refers to the purchase and sale of stocks close to their ex-dividend date to artificially inflate the dividend yield that a fund advertises.

Households also face significant challenges in terms of financial advice. Using comprehensive data from Canada, Foerster et al. (2017) showed that financial advice is better explained by adviser's characteristics rather than household's needs. Moreover, this advice appears to cost about $2.7 \%$ per year in fees, significantly more than the cost of a simple life-cycle mutual fund. While financial advisers may help their clients by encouraging them to invest in risky assets, as suggested by Gennaioli et al. (2015), these results raise the question of whether a lower-cost solution can be made available to households, especially given the recent trend towards automation (robo-advisors). 
Another stream of research from the field of behavioral corporate finance proves that corporate managers are aware of investors' behavioral biases and readily exploit them (Baker and Wurgler, 2013). For example, managers seem to realize that investors prefer low-priced stocks and often issue equity when this preference is strongest (Baker et al., 2009).

More importantly, there is a growing body of evidence that corporations act to boost share prices above their fundamental value through manipulation. The classic example is of a company changing its name for reasons not related to strategic actions. Cooper et al. (2001) documented that phenomenon during the dot-com boom of the late 1990s, when a change to an internetrelated name produced cumulative abnormal returns of about $70 \%$ for the 10 days after the announcement. Interestingly, the opposite action after the crash led to the same effect. Cooper et al. (2005) estimated that the deletion of ".com" from a company name in the years following produced cumulative abnormal returns of about $60 \%$ in the 60 days after the announcement. ${ }^{12}$

Similarly, corporate managers adjust advertising to attract investor attention and increase short-term stock market returns (Lou, 2014). As a result, investors who are prone to responding to non-relevant information drive stock prices higher and suffer losses in the long-term.

\section{HOUSEHOLD FINANCE: LIABILITIES}

Many studies suggest that households are prone to excessive ${ }^{13}$ and overly expensive borrowing (Stango and Zinman, 2009b; Gathergood 2012; Gerardi et al. 2013). Evidence suggests households may conclude debt contracts to accommodate impulse purchases, chose contracts sub-optimally, and leave money on the table by mismanaging credit card repayments or by failing to refinance mortgages. Some studies also find that businesses are aware of households' mistakes and use that to their advantage, while competition among lenders does not necessarily improve outcomes for borrowers.

While the most important facts related to household investment decisions were known before the financial crisis, the accumulation of stylized facts about borrowing decisions has mostly come in the last 10 years. Consequently, the literature on debt choices is still less developed than on the asset side of households' balance sheets (Cordray, 2013; Zinman, 2015). Meanwhile, household borrowing decisions are not any less important for households themselves and should be equally interesting for scholarly study. ${ }^{14}$ Zinman (2015) illustrates this point nicely:

The key fact is that no extant model, whether neoclassical or behavioral, can generate enough credit card debt [...]. This puzzle raises fundamental questions about the value and shape of preference parameters; the nature of expectation formation; consumers' (possibly biased) perceptions of interest rates and opportunity costs; the interactions of consumers, suppliers, and marketers; and their implications for the allocation of massive amounts of resources over the various horizons that affect the macroeconomy. In these respects, I find this puzzle no less interesting than, say, the equity premium puzzle. Yet orders of magnitude more ink have been spilled trying to document and explain the equity premium than credit card overborrowing.

This difference in attention and timing has resulted in at least two noteworthy consequences.

First, in contrast to the literature on household investments, studies of borrowing decisions are less comprehensive and systematic in their explanations of the phenomenon in question. These studies rarely aim to contrast competing theories and instead focus on explaining behavioral heterogeneity.

Secondly, since debt-related research is less grounded in traditional financial economics, there are fewer normative models that define how strictly optimal borrowing behavior should look like in principle. As a result, these studies are more explorative and simultaneously more behavioral in nature (more open to behavioral explanations) than research related to household investment decisions.

The rest of this section reviews the empirical evidence related to household borrowing decisions that aims to describe and explain the actions of households. More specifically, this section reviews how households choose debt contracts and how they manage their debt, placing special focus on the choice between fixed-rate and adjustable-rate mortgages, given their potential significance for macrofinancial stability. The final sub-section presents evidence of rent extraction.

\footnotetext{
${ }^{12}$ The bitcoin price surge in late 2017 is another example. For instance, the stock price of On-line Plc., a British company investing in information businesses, soared almost $400 \%$ on October 27 th in response to the company's plans to change its name to On-line Blockchain Plc.

${ }^{13}$ See Zinman (2014) for a discussion of supply-side factors, namely whether markets over- or under-supply credit.

${ }^{14}$ Tufano (2009) notes that the study of household borrowing decisions existed mostly within the context of relatively less prestigious consumer science, while the study

of investment decisions was always a part of financial economics, which was and still is among the most prestigious topics in finance research.
} 


\subsection{Choice of debt contracts}

Although the choice of a mortgage is the most important financial decision most households will ever make, consumers do not spend much time choosing a mortgage. Damen and Buyst (2016) point out that about $20 \%$ of European households do not compare mortgage products and take the first mortgage they consider. Similarly, in the U.S., many consumers spend the same amount of time choosing a vacation place as they do a mortgage (Finkelstein, 2010). This may constitute an enormous financial mistake; Damen and Buyst (2016) estimated that a borrower who chooses from five mortgage offers may save an average of EUR 7,000 in net present value.

Either because of insufficient effort or mistakes in analysis (likely both), households end up with non-optimal debt contracts. For example, in consumer credit, Agarwal et al. (2015a) showed that about $40 \%$ of U.S. households choose sub-optimal credit contracts, incurring hundreds of dollars of avoidable interest charges. Stango and Zinman (2016) paint an even bleaker picture, showing that the difference in interest rates between credit card shoppers (those who compare offers) and non-shoppers is equal to the difference in interest rates between individuals with the highest and lowest credit scores.

In a more substantial showcase of a deviation from rationality assumptions, Agarwal et al. (2010) showed that individuals take out payday loans at astronomical interest rates even when much cheaper forms of credit are available to them. ${ }^{15}$

\section{Constraints}

The literature on the role of constraints in the choice of a credit contract is mostly focused on the effects of financial literacy. For instance, in early studies, Moore (2003) reported that individuals in the U.S. who have a lower level of financial literacy also tend to have more costly mortgages, while Bucks and Pence (2008) showed that low-income and less educated borrowers choose mortgage contracts without a proper understanding of its terms and are more likely to end up with riskier mortgages (for a more recent paper, see Gathergood and Weber, 2017).

Those findings are universal across the world. For example, using Italy as a case study, Fornero et al. (2011) found that financially literate households are more likely to shop around and compare mortgages offers, choose an optimal mortgage contract, and less likely to experience delays in making repayments.

Similarly, Gerardi et al. (2013) linked basic mathematical abilities and the propensity to default on a mortgage. The authors found that households with higher mathematical skills are more likely to choose an optimal mortgage contract and, as a result, are less likely to default.

Finally, Lusardi and Tufano (2009) examined the role of specific debt literacy and concluded that individuals with lower literacy tend to incur higher transaction and debt servicing costs. The authors estimated that up to one-third of charges and fees paid by less financially literate individuals can be attributed to ignorance. Interestingly, the study also showed that the elderly tend to overestimate their level of financial knowledge, which (as the authors suggest) may help to explain the common incidences of financial fraud against them.

\section{Non-standard preferences}

As might be expected, households with inconsistent time preferences are prone to make non-optimal decisions when choosing debt contracts. The empirical evidence supports this hypothesis.

Gathergood (2012) examined the relationship between self-control, financial literacy, and over-indebtedness in the context of the credit card market in the U.K. He found that while both factors matter, the lack of self-control plays a bigger role in explaining over-indebtedness than does financial illiteracy. Likewise, Meier and Sprenger (2010) showed that present-biased time preferences correlate with credit card borrowing. Their results indicate that present-biased individuals are more likely to have credit card debt and to hold more debt, controlling for disposable income and credit constraints. ${ }^{16}$

Another way of viewing this behavioral issue is to look at impulsivity (noting that it might be difficult to distinguish between impulsivity, present bias, and limited self-control). Anderloni et al. (2012) found that impatient, short-sighted behavior patterns increase households' financial vulnerability. However, Vieira et al. (2016) pointed out that impulsive individuals may be aware of the negative consequences of debt and this understanding may compensate for the high level of impulsivity.

\footnotetext{
${ }^{15}$ While payday loans are controversial because of annualized interest rates of over $500 \%$, empirical evidence suggests they may be not as harmful as perceived by the public. For instance, Karlan and Zinman (2010) demonstrated that the expansion of credit in South Africa, even at $200 \%$ annual interest rates, still improved economic outcomes for borrowers. Carter and Skimmyhorn (2016) showed that exposure to payday loans does not negatively affect labor and credit outcomes for military personnel, while Zinman (2010) provided evidence that if access to payday loans is restricted by regulation, payday borrowers shift into inferior and more harmful substitutes.

${ }^{16}$ It is possible to conclude that if bad financial decisions are made due to a lack of self-control and poor financial decisions lead to poverty, then a lack of self-control is a cause of poverty. While this conclusion may seem plausible, the direction of causality is not clear and may work in a different direction (see Bernheim et al., 2015).
} 


\section{(Biased) beliefs}

Several studies suggest the earlier-mentioned (in the context of under-saving) exponential growth bias can explain the tendency to underestimate future debt servicing costs which, in turn, leads to a non-optimal choice of debt contracts (Eisenstein and Hoch, 2007; McKenzie and Liersch, 2011).

Like the exponential growth bias, which influences decisions on both sides of the balance sheet, optimism not only can lead to insufficient savings but also overborrowing. Using unique household data from Finland, Hyytinen and Putkuri (2012) found that households that make the most optimistic forecast errors are more likely to have more overall debt and more likely to experience difficulties managing it.

\subsection{Choice between fixed rate and adjustable rate mortgages}

The choice between fixed-rate (FRM) and adjustable-rate (ARM) mortgages is an important decision for households that has enormous consequences for the aggregate economy. The global financial crisis sparked an interest in the determinants of that choice as it raised the concern that households make this decision non-optimally by ignoring the risks associated with ARMs.

It is difficult to argue that the spike in popularity of ARMs in the U.S. in the mid-2000s was the main driver of the subprime ${ }^{17}$ mortgage ${ }^{18}$ boom and the following bust. Rather it seems that the underlying cause lies in the fact that borrowers who were the most financially vulnerable (those sensitive to a repayment shock from rising interest rates and to an income shock following the recession) ended up with the riskiest mortgages (Demyanyk, 2009; Demyanyk and Van Hemert, 2011; Campbell and Cocco, 2015). The fact that U.S. delinquencies and foreclosure rates for subprime ARMs were substantially higher than for subprime FRMs during the crisis (Mayer et al., 2009; FCIC, 2011) only intensified the study of the determinants of households' choices.

Generally, the empirical literature finds that the variation in the share of ARMs across and within countries is too great to be explained by the standard framework of rational expectations. According to that framework, households must base their decision on the difference between the current long-term interest rate (a proxy for the cost of the FRM) and the average expected future short-term rates (a proxy for the cost of the ARM) over the contract period. However, the fluctuation in the share of ARMs is too great to be explained by changes in that differential simply because the implied changes in expectations about future short-term rates are too large to be considered reasonable and realistic.

For example, the share of newly originated ARMs in the U.S. varied between $10 \%$ and $70 \%$ from 1985 to 2006 (Koijen et al., 2009). In Belgium, the share fell from 62\% in 2004 to $8 \%$ in 2006, then recovered to $58 \%$ in 2010 and fell again to 5\% in 2012 (Damen and Buyst, 2013). In Italy, the share fell from over 80\% in 2004 to less than $40 \%$ in 2008 and then returned to between $60 \%$ and $80 \%$ after 2010 (Zocchi, 2013). Those variations are too large to be explained by changing macroeconomic circumstances.

Against this backdrop, however, Koijen et al. (2009) conclude that households make near-optimal mortgage choices by capturing a normatively correct relative attractiveness between ARM and FRM contracts. The authors stressed that households' cognitive limitations do not allow them to calculate the relevant time variation in bond risk premia (which is the true determinant of the relative attractiveness of ARMs). Instead, individuals rely on a simple rule of thumb: the difference between the long-term interest rates approximated using the five-year Treasury bond yield and the three-year average of short-term interest rates, which is sufficiently close to a true benchmark.

However, while Badarinza et al. (2017) confirmed that such a rule helps determine the near-optimal ARM share in the case of the United States, they also found no evidence that this mechanism works well in other countries in their sample. Furthermore, the model proposed by Koijen et al. (2009) cannot account for the heterogeneity of choices at the individual level as it relies on aggregated data.

\section{Constraints}

Campbell and Cocco $(2003,2015)$ authored the most popular framework for understanding the choice by households between FRMs and ARMs. They explore household mortgage choices under borrowing constraints. The presence of a constraint is likely to cause households to focus on current interest costs rather than long-term costs. This line of reasoning implies that the current FRM-ARM spread will be the primary determinant of the contract choice and predicts that households that chose ARMs are those who are more financially constrained. More financially constrained households tend to prefer ARMs either because they usually carry a teaser rate or because ARMs carry unusually low short-term interest rates, as was the case prior to the global financial crisis.

\footnotetext{
17 Contrary to widespread perception, ARMs are not inherently riskier than FRMs. Campbell and Cocco (2015) showed that both types are similarly sensitive to housing prices and experience similar default rates. The drivers of default, however, are different. The probability of ARM default increases when rising interest rates drive up required payments. For this reason, the ARM default risk is highest for mortgages originated at low rates (which made the ARMs riskiest in the mid-2000s).

${ }_{18}$ The literature considers both supply-side (e.g., declines in lending standards) and demand-side factors. This paper considers only the latter.
} 
While the empirical evidence generally supports this notion, it also indicates that other factors mediate the effect.

Using data from the survey of consumer finances, Coulibaly and Li (2009) concluded that financially constrained households are somewhat more likely to prefer ARMs. At the same time, they found that risk aversion is negatively associated with a tendency to choose ARMs, while affordability considerations do not affect less risk-averse borrowers.

Another deviation from the strict emphasis on financial constraint follows from Bergstresser and Beshears (2010). Relying on the same survey of consumer finances, they showed that less suspicious and (consistent with Bucks and Pence, 2008) less knowledgeable (about the exact terms of their mortgages) households are disproportionately those who chose ARMs in the years preceding the financial crisis. Similarly, Johnson and Li (2014) showed that the consumption growth of U.S. ARM borrowers is sensitive to past income, which can be interpreted as an indication of financial constraint. In addition, these borrowers are younger and less educated and have more difficulty managing their debt.

Studies from European countries generally reach a similar conclusion - while ARM borrowers are financially constrained, other factors mitigate that effect.

In a pre-crisis paper, Paiella and Pozzolo (2007) found that Italian households are more likely to choose ARMs if they have high expenditures on non-durable goods (financially constrained). While that paper used a sound proxy for financial constraint, it used a limited set of explanatory variables, which makes the finding difficult to generalize.

Overcoming that limitation, Fornero et al. (2011) assessed the role of financial literacy in the FRM-ARM choice. The authors showed that financially constrained households with higher mortgage-to-income ratios are more likely to choose an ARM if they also have a low level of financial literacy. At the same time, the paper also found that households with a higher level of financial wealth also tend to choose ARMs over FRMs, suggesting that rich and poor households make decisions differently.

Echoing that conclusion, Damen and Buyst (2013) found that low- and high-income households in Flanders, Belgium choose ARMs for different reasons. While poor households tend to prefer ARMs because they are financially constrained, wealthy households choose ARMs if they can afford changes in future interest payments.

Finally, Hullgren and Söderberg (2016) showed that ARM borrowers in Sweden tend to be younger (thus, less experienced), financially vulnerable, and more influenced by media.

\section{Box 1. Determinants of demand for foreign currency loans}

While the determinants of the FRM-ARM choice are important for policymakers in developed countries, their counterparts in the developing world may be more interested in understanding the choice by households between foreign currency loans (FCLs) and local currency loans (LCLs), especially mortgages. For instance, FCLs have a $25 \%$ share of all loans in Latin America, $40 \%$ in the Middle East, and more than $50 \%$ in Central and Eastern European countries collectively (Beckmann and Stix, 2015).

Early studies concluded that FCLs may be individually and socially optimal (Ize and Yeyati, 2003). However, the experience of the global financial crisis, especially in Eastern Europe, casts doubt on that view (Brzoza-Brzezina et al., 2017).

Given the crisis-inspired interest in understanding demand-side determinants of foreign currency borrowing, somewhat surprisingly, the literature addressing this question remains scarce and provides contradictory conclusions.

Among single-country studies, Pellényi and Bilek (2009) documented that FC borrowers in Hungary do not differ from LC borrowers in terms of financial literacy and risk aversion. On the contrary, Beer et al. (2010) found that FCLs in Austria are most popular among risk-seeking and wealthier households, while two more recent studies added that Austrian FC borrowers have substantially higher risk buffers and can tolerate exchange rate risk (Albacete et al., 2012; Albacete and Lindner, 2015).

Cross-country studies present fewer contradictions as they have mostly focused on different aspects of FCL demand. Csajbók et al. (2010) showed that households with FCLs have greater liquidity constraints and that the "fear of floating" monetary regime tend to increase demand for FCLs as households expect small variations in the FX rate. In part contradicting the findings of Beer et al. (2010), Beckmann and Stix (2015) documented that knowledge about exchange rate risk decreases demand for FCLs. Lastly, Beckmann (2017) tested and confirmed the hypothesis that household expectations of government debt relief will increase demand for FCLs. 


\section{Non-standard preferences}

The preference for ARMs by financially constrained households may be a sign of present bias and myopia. For instance, Damen and Buyst (2013) interpret their result as an example of myopic behavior. Finally, in-line with the findings of Bailey et al. (2017), social networks may influence households' judgment regarding the relative attractiveness of ARMs over FRMs.

Households may also choose ARMs for another reason. Botsch and Malmendier (2015) suggest the choice between fixed- and adjustable-rate mortgages may be indicative of inflation expectations. Households that place a greater subjective probability on high future inflation may perceive FRMs as a type of hedge, exhibiting a non-standard preference.

\section{(Biased) beliefs}

The existing literature on the FRM-ARM choice does not directly examine the role of (biased) beliefs. However, it is reasonable to assume that ARM borrowers may suffer from the exponential growth bias and underestimate the income risk they face from rising interest rates. These borrowers may also underestimate the potential variability of interest rates due to naive learning from recent experience (assuming that recent variability in interest rates is indicative of future volatility). Additionally, households may overestimate future income growth due to optimism or overconfidence and, therefore, downplay the income risk. Future research will likely test these hypotheses.

\subsection{Management of debt contracts}

The literature that aims to understand how households manage debt obligations can be divided into two groups: studies of household decisions to refinance mortgages and those analyzing the optimality of consumer debt repayments, mostly credit card debt.

In the first case, Keys et al. (2016) found that $20 \%$ of households for whom refinancing would be optimal and feasible, still had not taken advantage of lower rates. The authors estimated that this (non)decision resulted in a new present average loss of $\$ 11,500$ per household. The failure to refinance suggests that despite high stakes in this case, households still make suboptimal financial decisions.

Along similar lines, Agarwal et al. (2015b) analyzed a sample of those who made refinancing decisions in 1998-2011 and found that about a half of those borrowers refinanced at rates at least 50 basis points above the best rate available to them. The authors also demonstrated that financially sophisticated borrowers made smaller mistakes, refinancing at rates closer to optimal.

In consumer credit, Stango and Zinman (2009b) estimated that more than half of annual expenses associated with checking and credit card accounts could be avoided with minor changes in behavior. Soll at al. (2013) examined the degree to which households misunderstand the relationship between credit card debt repayments and debt reduction, or how changes in monthly debt repayment amounts affect debt repayment time. They found that households are insufficiently sensitive to the interest-to-principal ratio, meaning that individuals may fail to realize that small increases in the monthly payment can result in a significant drop in the repayment time when the interest-to-principal ratio is high. Echoing that result, Keys and Wang (2016) documented that in a large dataset covering one-quarter of the U.S. credit card market, almost $30 \%$ of accounts make only the lowest monthly repayment allowed (usually much smaller than optimal for most households).

More recently, Ponce et al. (2017) used data from Mexico to assess whether consumers minimize financing costs by borrowing on lower-interest cards. They found that, on average, households allocate a large proportion of their debt to highinterest credit cards, even when they could save a substantial amount, leaving considerable money on the table. In a related paper, Gathergood et al. (2017) documented similar behavior among UK households.

\section{Constraints}

The mismanagement of debt repayments may be the result of inertia (a low probability of refinancing) and inattention (insensitivity to refinancing incentives), which implies that cognitive constraints play an important role. The empirical evidence is largely consistent with this hypothesis (Andersen et al., 2017).

Furthermore, many studies highlight the role of financial literacy and sophistication. Hilgert et al. (2003) documented a positive relationship between financial literacy and the quality of many debt management practices, such as payment discipline, maintaining a low payment-to-income ratio, and shopping for better credit card offers. Likewise, Campbell (2006) reported that low-income and less-educated households are less likely to refinance mortgages in a favorable interest rate environment.

However, not all types of education seem equally beneficial. Brown et al. (2016) showed that while backgrounds in mathematics and finance positively affect repayment behavior, somewhat surprisingly, general economics training increases the probability of both holding debt and having trouble with repayment.

Finally, the above-mentioned study by Andersen et al. (2017) found that inertia and inattention are less prevalent among better educated and wealthier (more sophisticated) individuals. 


\section{Non-standard preferences}

Inconsistent time preference is one of the likeliest factors behind household financial mistakes, probably in all cases related to debt choices. In this sense, debt management is not an exception, as more impatient households are less likely to stick to their self-defined debt payment plans (Kuchler, 2015). In her study, Kuchler also noted that planned pay-downs by sophisticated individuals (who are aware of their impatience) are more indicative of future actions than for naive individuals (who are unaware of their impatience).

\section{(Biased) beliefs}

Why do households in the study by Keys and Wang (2016) regularly make only minimum monthly debt repayments? One possibility is that these individuals have liquidity constraints or are inattentive and prone to inertia. Another possibility is that existing minimum payments may affect payment choices due to the anchoring bias, basically suggesting to households that the default amount of repayment (minimum payment) is an optimal one. In this case, individuals, if they suffer from the anchoring bias, would consider non-informative clues about the amount of the minimum payment as meaningful and would likely to stick to it if they lack better information.

Using a robust identification strategy, Keys and Wang (2016) tested this hypothesis and found that at least $10 \%$ of all households in their sample anchor their repayment choice to the minimum payment. That shows that those households suffer from the anchoring bias.

\subsection{Rent extraction}

An important question for policymakers is whether competition among lenders helps borrowers make optimal credit decisions. Unfortunately, as Heidhues and Koszegi (2010) have shown, even when credit card companies compete for profit, borrowers who underestimate their borrowing amount and their debt repayment timeframe will incur large fees and interest charges. ${ }^{19}$

Furthermore, lenders seem to screen for behavioral biases and target less knowledgeable and less sophisticated individuals. In a series of recent studies, Ru and Schoar (2016) found that card issuers target less-educated customers by using rewards programs to screen for behavioral biases, while Ponce et al. (2017) concluded that Brazilian banks take advantage of households' failure to borrow from low-interest credit cards. In addition, field evidence suggests employees of financial institutions provide little information about avoidable fees, especially to less knowledgeable individuals (Giné et al., 2014).

Additionally, Zocchi (2013) cites a study by Valletta and Zocchi (2009) that found that financial advice plays a major role in the choice between fixed-rate and adjustable-rate mortgages for many households and that almost two-thirds of Italian borrowers who were advised by a bank went on to choose an ARM. They concluded that by offering an ARM with a teaser rate, banks reduced their margin (for a limited period) to increase their market share. According to that study, that practice distorts the market, as it indiscriminately favors the preference for riskier mortgage contracts.

Several mortgage papers also point to manipulative sales tactics that result in price discrimination (e.g., Agarwal et al., 2016) and that these practices have an effect at the aggregate level. For instance, Gurun et al. (2016) found that regions with the highest intensity of advertising of mortgage broker services are those with the most expensive mortgages, and that those advertising practices are most effective when they target poor and less-informed individuals.

Finally, several studies show that predatory lending practices are prevalent and contribute to higher mortgage default rates (Agarwal et al., 2014a), while anti-predatory lending laws and counseling programs improve mortgage outcomes (Bostic et al., 2012; Agarwal et al., 2014b).

\section{CONCLUSIONS AND DISCUSSION}

Despite the progress in household finance in the last 10 years, the field remains relatively unknown to a wider academic audience and to the public. While improved familiarity by the public with the findings in other related sub-fields of behavioral finance (such as individual investor behavior) helps popularize some of the important findings, a literature review in household finance has the potential to benefit a wide range of readers, especially young researchers and policymakers.

The empirical evidence on household investment and debt choices presented above suggests four major conclusions.

First, the evidence rejects the somewhat popular notion that (beyond a narrow domain of active stock market trading) household decision-making is close to optimal, if not fully rational. Indeed, households save, participate, and diversify too little, and take on too much insufficiently considered debt and manage it inefficiently. Similarly, there is little evidence that

${ }_{19}$ This paper is part of the larger literature that shows that competition does not necessarily reduce deceptive and non-ethical behavior. For instance, Zinman and Zitzewitz (2016) showed that ski resorts substantially overreport natural snowfall on weekends, and competition does not hamper this practice. 
these mistakes are made exclusively by the poor and financially illiterate. While those households are more likely to make costly financial mistakes, sophisticated and wealthy households do not make near-optimal financial decisions either.

As a result, there is a question of whether the do-it-yourself policy view of household financial decisions could be seriously flawed. While we do not expect individuals to use health care services in a do-it-yourself institutional environment and generally discourage self-treatment, we still expect that households should make autonomous and independent financial decisions. This happens even though modern financial markets are no less complex than modern medicine. Since households make costly financial mistakes that result in negative consequences for individuals and societies, policymakers could benefit from shifting their perspective from the opportunities created by modern finance to the challenges it brings to households.

Secondly, the empirical evidence suggests that basically all household finance phenomena have compelling "rational" and "behavioral" explanations. Moreover, these explanations are likely to complement and interact with one another, rather than be mutually exclusive. This observation highlights a potential danger of ideology, which according to Jelveh et al. (2015) influences the results of academic research in economics. Researchers with a narrow professional background and strong ideological preferences for the standard or behavioral perspective may fail to consider equally likely explanations of observed phenomena. By doing so, they may contribute to the formation and propagation of harmful narratives that can negatively influence policy decisions that will fail to deliver society-wide beneficial outcomes.

Thirdly, households' behavioral weaknesses do not exist in isolation from institutional arrangements and the regulatory environment. The empirical evidence seems to reject a long-standing belief that competition tends to eliminate opportunities for rent extraction. Instead, the studies find that businesses are aware of potential mistakes by households and do exploit them. In terms of investment decisions, this means that better regulation has the potential to improve the effectiveness of financial advice (to increase benefits and reduce costs) and increase market efficiency (by limiting the ability of managers to boost share prices above their fundamental value). In the domain of borrowing decisions, better regulation has the potential to improve macrofinancial stability as a result of better allocation of credit (by ensuring that household circumstances and characteristics match with the features of debt contracts).

Finally, it is quite easy to notice that financial literacy seems to play an important role in determining the quality of household investment and borrowing decisions. In this sense, policymakers may view the goal of improving household financial literacy as low-hanging fruit.

While it is difficult to make a case against improving financial literacy, a word of caution is in order. Let's recall the example provided by Gathergood (2012) who examined the relationship between self-control, financial literacy, and over-indebtedness in the credit card market. Gathergood concluded that while financial literacy indeed plays an important role in determining the quality of decision-making, a lack of self-control by households plays an even more significant role.

More generally, a wave of recent studies cast serious doubt on the effectiveness of financial education. For example, in a meta-analysis of the relationship between financial education interventions and financial behaviors covering more than 200 previous studies, Fernandes et al. (2014) concluded that (1) interventions to improve financial literacy have a limited effect on financial behavior, and that (2) the effect of those interventions rapidly decay over time.

Taken together with the abundance of empirical evidence on rent extraction, the power of behavioral interventions, and the effects of supply-side factors that influence household financial behaviors, it is reasonable to assume that an excessive focus on improving financial literacy is not justified if taken in isolation from other determinants of household behaviors.

\section{References}

- Agarwal S., Amromin G., Ben-David I., Chomsisengphet S., Evanoff D. D. (2014a). Predatory lending and the subprime crisis. Journal of Financial Economics, Vol. 113, No. 1, pp. 29-52.

- Agarwal S., Amromin G., Ben-David I., Chomsisengphet S., Evanoff D. D. (2014b). The effectiveness of mandatory mortgage counseling: can one dissuade borrowers from choosing risky mortgages? NBER Working Paper No. w19920. Available at SSRN: https://ssrn.com/abstract=2400265

- Agarwal S., Amromin G., Ben-David I., Evanoff D. D. (2016). Loan product steering in mortgage markets. Charles A. Dice Center Working Paper No. 2016-18; Fisher College of Business Working Paper No. 2016-03-18; Charles A. Dice Center Working Paper No. 2016-18. Available at SSRN: https://ssrn.com/abstract=2841312

- Agarwal S., Chomsisengphet S., Lim C. (2017). What shapes consumer choice and financial products? -A Review. Georgetown McDonough School of Business Research Paper No. 2875886. Available at SSRN: https://ssrn.com/abstract=2875886

- Agarwal S., Chomsisengphet S., Liu C., Souleles N.S. (2015a). Do consumers choose the right credit contracts? Review of Corporate Finance Studies, Vol. 4, No. 2, pp. 239-257. 
- Agarwal S., Rosen R. J., Yao V. (2015b). Why do borrowers make mortgage refinancing mistakes? Management Science, Vol. 62, No. 12, pp. 3494-3509.

- Agarwal S., Skiba P. M., Tobacman J. (2010). Payday loans and credit cards: new liquidity and credit scoring puzzles? NBER Working Paper No. w14659. Available at SSRN: https://ssrn.com/abstract=1332598

- Agarwal, S., S. Chomsisengphet, and C. Lim. (2017). What shapes consumer choice and financial products? A Review. Annual Review of Financial Economic, Vol. 9, No. 1, pp. 127-146.

- Akerlof G. A., Kranton R.E. (2010). Identity economics: how identities shape our work, wages, and well-being. Princeton University Press, Princeton.

- Albacete N., Fessler P., Schürz M. (2012). Risk buffer profiles of foreign currency mortgage holders. Financial stability report, No. 23, pp. 58-71.

- Albacete N., Lindner P. (2015). Foreign currency borrowers in Austria - evidence from the Household Finance and Consumption Survey. Financial Stability Report, No, 29, pp. 93-109.

- Anderloni L., Bacchiocchi E., Vandone D. (2012). Household financial vulnerability: an empirical analysis. Research in Economics, Vol. 66, No. 3, pp. 284-296.

- Andersen S., Campbell J. Y., Nielsen K. M., Ramadorai T. (2017). Inattention and inertia in household finance: evidence from the Danish mortgage market. Working Paper. Available at SSRN: https://ssrn.com/abstract=2463575

- Andersen S., Hanspal T., Nielsen K. M. (2016). Once bitten, twice shy: the role of inertia and personal experiences in risk taking. CEPR Discussion Paper No. DP11504. Available at SSRN: https://ssrn.com/abstract=2840701

- Anderson A. (2013). Trading and under-diversification. Review of Finance, Vol. 17, No. 5, pp. 1699-1741.

- Badarinza C., Campbell J. Y., Ramadorai T. (2017). What calls to ARMs? International evidence on interest rates and the choice of adjustable-rate mortgages. Management Science. Posted online. Available at:

http://pubsonline.informs.org/doi/abs/10.1287/mnsc.2016.2629

- Bailey M., Cao R., Kuchler T., Stroebel J. (2017). The economic effects of social networks: evidence from the housing market. Working Paper. Available at SSRN: https://ssrn.com/abstract $=2753881$

- Baker M., Greenwood R., Wurgler J. (2009). Catering through nominal share prices. Journal of Finance. Vol. 64, No. 6, pp. 2559-2590.

- Baker M., Wurgler J. (2013). Behavioral corporate finance: an updated survey. In Handbook of the Economics of Finance, G. M. Constantinides, M. Harris, and R. M. Stulz, eds., Vol. 2, Part A, pp. 357-424. Elsevier, Amsterdam.

- Balasuriya J., Gough O., Vasileva K. (2014). Do optimists plan for retirement? A behavioural explanation for non-participation in pension schemes. Economics Letters. Vol. 125, No. 3, pp. 396-399.

- Barber B. M., Lee Y.-T., Liu Y.-J., Odean T. (2014). The cross-section of speculator skill: evidence from day trading. Journal of Financial Markets, Vol. 18, pp. 1-24.

- Barber B. M., Odean T. (2000). Trading is hazardous to your wealth: the common stock investment performance of individual investors. Journal of Finance. Vol. 55, No. 2, pp. 773-806.

- Barber B. M., Odean T. (2013). The behavior of individual investors. In Handbook of the Economics of Finance, Vol. 2, Part B, pp. 1533-1570, Elsevier, Amsterdam.

- Barber B. M., Odean T., Zheng L. (2005). Out of sight, out of mind: the effects of expenses on mutual fund flows. Journal of Business, Vol. 78, No. 6, pp. 2095-2120.

- Beckmann E. (2017). How does foreign currency debt relief affect households loan demand? Evidence from the OeNB Euro Survey in CESEE. Focus on European Economic Integration, Vol. 1, pp. 8-32.

- Beckmann E., Stix H. (2015). Foreign currency borrowing and knowledge about exchange rate risk. Journal of Economic Behavior \& Organization, Vol. 112, pp. 1-16.

- Beer C., Ongena S., Peter M. (2010). Borrowing in foreign currency: austrian households as carry traders. Journal of Banking \& Finance, Vol. 34, No. 9, pp. 2198-2211. 
- Benartzi S. (2001). Excessive extrapolation and the allocation of 401 (k) accounts to company stock. Journal of Finance, Vol. 56, No. 5, pp. 1747-1764.

- Bergstresser D., Beshears J. L. (2010). Who selected adjustable-rate mortgages? Evidence from the 1989-2007 Surveys of Consumer Finances. Harvard Business School Finance Working Paper No. 10-083. Available at SSRN: https://ssrn.com/abstract=1573625

- Bernheim B. D., Ray D., Yeltekin S. (2015). Poverty and self-control. Econometrica, Vol. 83, No. 5, pp. 1877-1911.

- Bernile G., Kumar A., Sulaeman J. (2015). Home away from home: geography of information and local investors. Review of Financial Studies, Vol. 28, No. 7, pp. 2009-2049.

- Bostic R., Chomsisengphet S., Engel K. C., McCoy P. A., Pennington-Cross A., Wachter S. (2012). Mortgage product substitution and state anti-predatory lending laws: better loans and better borrowers? Atlantic Economic Journal, Vol. 40, No. 3, pp. 273-294.

- Botsch M. J., Malmendier U. (2015). Inflation experiences and contract choice. Evidence from residential mortgages. Working Paper. Available at: https://www.aeaweb.org/conference/2016/retrieve.php?pdfid=961

- Briggs J., Cesarini D., Lindqvist E., Ostling R. (2015). Wealth and stock market participation: estimating the causal effect from Swedish lotteries. Working Paper. Available at: http://w4.stern.nyu.edu/finance/docs/pdfs/Seminars/1501f-cesarini.pdf

- Brown M., Grigsby J., Van der Klaauw W., Wen J., Zafar B. (2016). Financial education and the debt behavior of the young. Review of Financial Studies, Vol. 29, No. 9, pp. 2490-2522.

- Brunetti M., Torricelli C. (2015). Second homes: households' life dream or (wrong) investment? CEIS Working Paper No. 351. Available at SSRN: https://ssrn.com/abstract=2639739

- Brzoza-Brzezina M., Kolasa M., Makarski K. (2017). Monetary and macroprudential policy with foreign currency loans. Forthcoming in the Journal of Macroeconomics. Posted online. Available at: http://www.sciencedirect.com/science/article/pii/S0164070417302756

- Bucks B., Pence K. (2008). Do borrowers know their mortgage terms? Journal of Urban Economics, Vol. 64, No. 2, pp. 218233.

- Calvet L. E., Campbell J. Y., Sodini P. (2007). Down or out: assessing the welfare costs of household investment mistakes. Journal of Political Economy, Vol. 115, No. 5, pp. 707-747.

- Calvet L., Haliassos M., Michaelides A. (2015). Introduction to JPEF special issue on household finance. Journal of Pension Economics \& Finance, Vol. 14, No. 4, pp. 329-331.

- Calvet, L., M. Gonzalez-Eiras, and P. Sodini (2004). Financial innovation, market participation, and asset prices. Journal of Financial and Quantitative Analysis, Vol. 39, No. 3, pp. 431-459.

- Campbell J. Y. (2006). Household finance. Journal of Finance, Vol. 61, No. 4, pp. 1553-1604.

- Campbell J. Y., Cocco J. F. (2003). Household risk management and optimal mortgage choice. Quarterly Journal of Economics, Vol. 118, No. 4, pp. 1449-1494.

- Campbell J. Y., Cocco J. F. (2015). A model of mortgage default. Journal of Finance, Vol. 70, No. 4, pp. 1495-1554.

- Carter S. P., Skimmyhorn W. (2016). Much ado about nothing? New evidence on the effects of payday lending on military members. Review of Economics and Statistics, Vol. 99, No. 4, pp. 606-621.

- Chetty R., Friedman J. N., Leth-Petersen S., Nielsen T. H., Olsen T. (2014). Active vs. passive decisions and crowd-out in retirement savings accounts: evidence from Denmark. Quarterly Journal of Economics, Vol. 129, No. 3, pp. 1141-1219.

- Choi J. J., Laibson D., Madrian B. C. (2011). 100 bills on the sidewalk: suboptimal investment in 401 (k) plans. Review of Economics and Statistics, Vol. 93, No. 3, pp. 748-763.

- Christelis D., Jappelli T., Padula M. (2010). Cognitive abilities and portfolio choice. European Economic Review, Vol. 54, No. 1, pp. 18-38.

- Cooper M. J., Dimitrov O., Rau P. R. (2001). A Rose.com by any other name. Journal of Finance, Vol. 56, No. 6, pp. 23712388. 
- Cooper M. J., Gulen H., Rau P. R. (2005). Changing names with style: mutual fund name changes and their effects on fund flows. Journal of Finance, Vol. 60, No. 6, pp. 2825-2858.

- Cordes H., Nolte S., Schneider J. C. (2017). On the dynamics and drivers of countercyclical risk aversion. Working Paper. Available at SSRN: https://ssrn.com/abstract=2918953

- Cordray R. (2013). Protecting consumers in the financial marketplace. The University of Chicago Legal Forum. Keynote address. Available at: https://goo.gl/NwxXBN

- Coulibaly B., Li G. (2009). Choice of mortgage contracts: evidence from the survey of consumer finances. Real Estate Economics, Vol. 37, No. 4, pp. 659-673.

- Csajbók A., Hudecz A., Tamási B. (2010). Foreign currency borrowing of housholds in new EU member states. MNB Occasional Papers 87. Available at: https://www.econstor.eu/handle/10419/83523

- Damen S., Buyst E. (2013). The myopic choice between fixed and adjustable rate mortgages in Flanders. Working Paper. Available at SSRN: https://ssrn.com/abstract $=2381533$

- Damen S., Buyst E. (2016). Mortgage shoppers: how much do they save? Real Estate Economics. Posted online. Available at: http://onlinelibrary.wiley.com/doi/10.1111/15406229.12167/full

- Davis S. J., Willen P. (2013). Occupation-level income shocks and asset returns: Their covariance and implications for portfolio choice. Quarterly Journal of Finance, Vol. 3, No. 03n04, pp. 1350011.

- Demirgüç-Kunt A., Klapper L.F. (2012). Measuring financial inclusion: the global findex database. World Bank Policy Research Working Paper No. 725. Available at: https://goo.gl/Wae29T

- Demyanyk Y. (2009). Ten myths about subprime mortgages. Federal Reserve Bank of Cleveland Economic Commentary. Available at: https://goo.gl/33a1i4

- Demyanyk Y., Van Hemert O. (2011). Understanding the subprime mortgage crisis. Review of Financial Studies, Vol. 24, No. 6, pp. 1848-1880.

- Doskeland T. M., Hvide H. K. (2011). Do individual investors have asymmetric information based on work experience? Journal of Finance, Vol. 66, No. 3, pp. 1011-1041.

- Eisenstein E. M., Hoch S. J. (2007). Intuitive compounding: framing, temporal perspective, and expertise. Working Paper. available at: https://goo.gl/A183oi

- FCIC, Financial Crisis Inquiry Commission, (2011). The financial crisis inquiry report, authorized edition: Final report of the National Commission on the Causes of the Financial and Economic Crisis in the United States. Public Affairs, New York.

- Fernandes D., Lynch Jr J. G., Netemeyer R. G. (2014). Financial literacy, financial education, and downstream financial behaviors. Management Science, Vol. 60, No. 8, pp. 1861-1883.

- Finkelstein B. (2010). Have consumers learned from mortgage mistakes? Mortgage Servicing News, Vol. 14, No. 7, pp. 2232.

- Foerster S., Linnainmaa J. T., Melzer B. T., Previtero A. (2017). Retail financial advice: does one size fit all? Journal of Finance, Vol. 72, No. 4, pp. 1441-1482.

- Fornero E., Monticone C., Trucchi S. (2011). The effect of financial literacy on mortgage choices. Netspar Discussion Paper No. 09/2011-085. Available at SSRN: https://ssrn.com/abstract $=1950040$

- Gathergood J. (2012). Self-control, financial literacy and consumer over-indebtedness. Journal of Economic Psychology, Vol. 33, No. 3, pp. 590-602.

- Gathergood J., Mahoney N., Stewart N., Weber J. (2017). How do individuals repay their debt? The balance-matching heuristic. Working Paper. Available at SSRN: https://ssrn.com/abstract=3000526

- Gathergood J., Weber J. (2017). Financial literacy, present bias and alternative mortgage products. Journal of Banking \& Finance, Vol. 78, pp. 58-83.

- Gennaioli N., Shleifer A., Vishny R. (2015). Money doctors. Journal of Finance, Vol. 70, No. 1, pp. 91-114. 
- Gerardi K., Goette L., Meier S. (2013). Numerical ability predicts mortgage default. Proceedings of the National Academy of Sciences, Vol. 110, No. 28, pp. 11267-11271.

- Giannetti M., Wang T. Y. (2016). Corporate scandals and household stock market participation. Journal of Finance, Vol. 71, No. 6, pp. 2591-2636.

- Giné X., Martinez Cuellar C., Mazer R. K. (2014). Financial (dis-) information: evidence from an audit study in Mexico. World Bank Policy Research Working Paper No. 6902. Available at SSRN: https://ssrn.com/abstract=2445748

- Glaser M., Iliewa Z., Weber M. (2016). Thinking about prices versus thinking about returns in financial markets. Working Paper. Available at SSRN: https://ssrn.com/abstract=2750064

- Goda G. S., Levy M., Manchester C. F., Sojourner A., Tasoff J. (2015). The role of time preferences and exponential-growth bias in retirement savings. NBER Working Paper No. w21482. Available at SSRN: https://ssrn.com/abstract=2649750

- Goetzmann W. N., Kumar A. (2008). Equity portfolio diversification. Review of Finance, Vol. 12, No. 3, pp. 433-463.

- Grinblatt M., Keloharju M. (2000). The investment behavior and performance of various investor types: a study of Finland's unique data set. Journal of Financial Economics, Vol. 55, No. 1, pp. 43-67.

- Grinblatt M., Keloharju M. (2009). Sensation seeking, overconfidence, and trading activity. Journal of Finance, Vol. 64, No. 2, pp. 549-578.

- Grosshans D., Zeisberger S. (2017). All's well that ends well? On the importance of how returns are achieved. Working Paper. Available at SSRN: https://ssrn.com/abstract=2579636

- Guiso L., Sapienza P., Zingales L. (2008). Trusting the stock market. Journal of Finance, Vol. 63, No. 6, pp. 2557-2600.

- Guiso L., Sodini P. (2013). Household finance: an emerging field. In Handbook of the Economics of Finance, Vol. 2, Part B, pp. 1397-1532, Elsevier, Amsterdam.

- Gurun U. G., Matvos G., Seru A. (2016). Advertising expensive mortgages. Journal of Finance, Vol. 71, No. 5, pp. $2371-2416$.

- Gurun U. G., Stoffman N., Yonker S. E. (2015). Trust busting: the effect of fraud on investor behavior. Kelley School of Business Research Paper No. 15-70. Available at SSRN: https://ssrn.com/abstract=2664307

- Haliassos M., Bertaut C. C. (1995). Why do so few hold stocks? Economic Journal, Vol. 105, No. 432, pp. 1110-1129.

- Harris L. E., Hartzmark S. M., Solomon D. H. (2015). Juicing the dividend yield: mutual funds and the demand for dividends. Journal of Financial Economics, Vol. 116, No. 3, pp. 433-451.

- Heidhues P., Koszegi B. (2010). Exploiting naivete about self-control in the credit market. American Economic Review, Vol. 100, No. 5, pp. 2279-2303.

- Hilgert M. A., Hogarth J. M., Beverly S. G. (2003). Household financial management: the connection between knowledge and behavior. Federal Reserve Bulletin, Vol. 89, pp. 309-322.

- Huberman G. (2001). Familiarity breeds investment. Review of Financial Studies, Vol. 14, No. 3, pp. 659-680.

- Hullgren M., Söderberg I.-L. (2016). Borrower characteristics and mortgage rate choice in Sweden. International Journal of Bank Marketing, Vol. 34, No. 5, pp. 649-669.

- Hurd M., Van Rooij M., Winter J. (2011). Stock market expectations of Dutch households. Journal of Applied Econometrics, Vol. 26, No. 3, pp. 416-436.

- Hyytinen A., Putkuri H. (2012). Household optimism and borrowing. Research Discussion Paper No. 21/2012. Bank of Finland. Available at SSRN: https://ssrn.com/abstract=2101025

- Illiashenko P. (2017). Behavioral finance: history and foundations. Visnyk of the National Bank of Ukraine, No. 239, pp. 2854.

- Ize A., Yeyati E. L. (2003). Financial dollarization. Journal of International Economics, Vol. 59, No. 2, pp. 323-347.

- Jelveh Z., Kogut B., Naidu S. (2015). Political language in economics. Columbia Business School Research Paper No. 14-57. Available at SSRN: https://ssrn.com/abstract $=2535453$ 
- Johnson K. W., Li G. (2014). Are adjustable-rate mortgage borrowers borrowing constrained? Real Estate Economics, Vol. 42 , No. 2, pp. 457-471.

- Karlan D., McConnell M., Mullainathan S., Zinman J. (2016). Getting to the top of mind: how reminders increase saving. Management Science, Vol. 62, No. 12, pp. 3393-3411.

- Karlan D., Ratan A. L., Zinman J. (2014). Savings by and for the poor: a research review and agenda. Review of Income and Wealth, Vol. 60, No. 1, pp. 36-78.

- Karlan D., Zinman J. (2010). Expanding credit access: using randomized supply decisions to estimate the impacts. Review of Financial Studies, Vol. 23, No. 1, pp. 433-464.

- Kast F., Meier S., Pomeranz D. (2012). Under-savers anonymous: evidence on self-help groups and peer pressure as a savings commitment device. IZA Discussion Paper No. 6311. Available at SSRN: https://ssrn.com/abstract=2003624

- Kaustia M., Knüpfer S. (2008). Do investors overweight personal experience? Evidence from IPO subscriptions. Journal of Finance, Vol. 63, No. 6, pp. 2679-2702.

- Kaustia M., Luotonen N. (2016). What drives the heterogeneity in portfolio choice? The role of institutional, traditional, and behavioral factors. Working Paper. Available at SSRN: https://ssrn.com/abstract=2845963

- Kaustia M., Torstila S. (2011). Stock market aversion? Political preferences and stock market participation. Journal of Financial Economics, Vol. 100, No. 1, pp. 98-112.

- Keys B. J., Pope D. G., Pope J. C. (2016). Failure to refinance. Journal of Financial Economics, Vol. 122, No. 3, pp. $482-499$.

- Keys B. J., Wang J. (2016). Minimum payments and debt paydown in consumer credit cards. NBER Working Paper No. w22742. Available at SSRN: https://ssrn.com/abstract $=2853238$

- Kézdi G., Willis R. J. (2009). Stock market expectations and portfolio choice of American households. Unpublished manuscript. Available at: https://goo.gl/MypABg

- Klapper L., Lusardi A., Van Oudheusden P. (2015). Financial literacy around the world. Standard \& Poor's Ratings Services Global Financial Literacy Survey. Available at: https://goo.gl/yJsZE5

- Koijen R. S., Van Hemert O., Van Nieuwerburgh S. (2009). Mortgage timing. Journal of Financial Economics, Vol. 93, No. 2, pp. 292-324.

- Korniotis G. M., Kumar A. (2013). Do portfolio distortions reflect superior information or psychological biases? Journal of Financial and Quantitative Analysis, Vol. 48, No. 1, pp. 1-45.

- Kuchler T. (2015). Sticking to your plan: empirical evidence on the role of present bias for credit card paydown. Working Paper. Available at SSRN: https://ssrn.com/abstract=2629158

- Larrimore J., Arthur-Bentil M., Dodini S., Thomas L. (2016). Federal Reserve Board issues. Report on the Economic WellBeing of U.S. Households. Available at: https://goo.gl/7v3GvN

- Lee Y.-T., Liu Y.-J., Zhu N. (2008). The costs of owning employer stocks: lessons from Taiwan. Journal of Financial and Quantitative Analysis, Vol. 43, No., 3, pp. 717-740.

- Levy M., Tasoff J. (2016). Exponential-growth bias and lifecycle consumption. Journal of the European Economic Association, Vol. 14 , No. 3, pp. 545-583.

- Lou D. (2014). Attracting investor attention through advertising. Review of Financial Studies, Vol. 27, No. 6, pp. $1797-1829$.

- Lusardi A., Michaud P.-C., Mitchell O. S. (2017a). Optimal financial knowledge and wealth inequality. Journal of Political Economy, Vol. 125, No. 2, pp. 431-477.

- Lusardi A., Mitchell O. S. (2014). The economic importance of financial literacy: theory and evidence. Journal of Economic Literature, Vol. 52, No. 1, pp. 5-44.

- Lusardi A., Mitchell O. S., Oggero N. (2017b). Debt and financial vulnerability on the verge of retirement. NBER Working Paper No. 23664. Available at: http://www.nber.org/papers/w23664

- Lusardi A., Tufano P. (2009). Debt literacy, financial experiences, and overindebtedness. NBER Working Paper No. w14808. Available at SSRN: https://ssrn.com/abstract $=1366208$ 
- Malmendier U., Nagel S. (2011). Depression babies: do macroeconomic experiences affect risk taking? Quarterly Journal of Economics, Vol. 126, No. 1, pp. 373-416.

- Massa M., Simonov A. (2006). Hedging, familiarity and portfolio choice. Review of Financial Studies, Vol. 19, No. 2, pp. 633-685.

- Mayer C., K. Pence, and S. M. Sherlund (2009). The rise in mortgage defaults. Journal of Economic Perspectives, Vol. 23, No. 1, pp. 27-50.

- McKenzie C. R., Liersch M. J. (2011). Misunderstanding savings growth: implications for retirement savings behavior. Journal of Marketing Research, Vol. 48, No. SPL, pp. S1-S13.

- Meier S., Sprenger C. (2010). Present-biased preferences and credit card borrowing. American Economic Journal: Applied Economics, Vol. 2, No. 1, pp. 193-210.

- Moore D. L. (2003). Survey of financial literacy in Washington State: Knowledge, behavior, attitudes, and experiences. Technical report. Available at: https://goo.gl/7nbW2W

- Munnell A. H., Webb A., Golub-Sass F. (2012). The national retirement risk index: an update. Center for Retirement Research at Boston College, No. 12-20, pp. 1-8.

- Nolte S., Schneider J. C. (2016). How price path characteristics shape investment behavior. Working Paper. Available at SSRN: https://ssrn.com/abstract=2883382

- Paiella M., Pozzolo A. F. (2007). Choosing between fixed-and adjustable-rate mortgages. In Household Credit Usage: Personal Debt and Mortgages, S. Agarwal, and B. W. Ambrose, eds., pp. 219-236. Palgrave Macmillan, New York.

- Pellényi G., Bilek P. (2009). Foreign currency borrowing: the case of Hungary. FINESS Working Paper. Available at: https:// www.econstor.eu/handle/10419/119503

- Perry V. G., Morris M. D. (2005). Who is in control? The role of self-perception, knowledge, and income in explaining consumer financial Behavior. Journal of Consumer Affairs, Vol. 39, No. 2, pp. 299-313.

- Polkovnichenko V. (2005). Household portfolio diversification: a case for rank-dependent preferences. Review of Financial Studies, Vol. 18, No. 4, pp. 1467-1502.

- Ponce A., Seira E., Zamarripa G. (2017). Borrowing on the wrong credit card? Evidence from Mexico. The American Economic Review, Vol. 107, No. 4, pp. 1335-1361.

- Puri M., Robinson D. T. (2007). Optimism and economic choice. Journal of Financial Economics, Vol. 86, No. 1, pp. 71-99.

- Rhee N., Boivie I. (2015). The continuing retirement savings crisis. Working Paper. Available at SSRN: https://ssrn.com/ abstract $=2785723$

- Roussanov N. (2010). Diversification and its discontents: idiosyncratic and entrepreneurial risk in the quest for social status. Journal of Finance, Vol. 65, No. 5, pp. 1755-1788.

- Ru H., Schoar A. (2016). Do credit card companies screen for behavioral biases? NBER Working Paper No. w22360. Available at SSRN: https://ssrn.com/abstract=2797954

- Seasholes M. S., Zhu N. (2010). Individual investors and local bias. Journal of Finance, Vol. 65, No. 5, pp. 1987-2010.

- Soll J. B., Keeney R. L., Larrick R. P. (2013). Consumer misunderstanding of credit card use, payments, and debt: causes and solutions. Journal of Public Policy \& Marketing, Vol. 32, No. 1, pp. 66-81.

- Stango V., Zinman J. (2009a). Exponential growth bias and household finance. Journal of Finance, Vol. 64, No. 6, pp. 28072849.

- Stango V., Zinman J. (2009b). What do consumers really pay on their checking and credit card accounts? Explicit, implicit, and avoidable costs. American Economic Review, Vol. 99, No. 2, pp. 424-429.

- Stango V., Zinman J. (2016). Borrowing high versus borrowing higher: price dispersion and shopping behavior in the US credit card market. Review of Financial Studies, Vol. 29, No. 4, pp. 979-1006.

- Tufano P. (2009). Consumer finance. Annual Review of Financial Economics, Vol. 1, No. 1, pp. 227-247. 
- Valletta M., Zocchi P. (2009). I risparmiatori e le banche. XVI Rapporto sul risparmio e suirisparmiatori in Italia BNL/Centro Einaudi. Unpublished manuscript.

- Van Horne J. C., Blume M. E., Friend I. (1975). The asset structure of individual portfolios and some implications for utility functions. Journal of Finance, Vol. 30, No. 2, pp. 585-603.

- Van Nieuwerburgh S., Veldkamp L. (2010). Information acquisition and underdiversification. Review of Economic Studies, Vol. 77, No. 2, pp. 779-805.

- Van Rooij M., Lusardi A., Alessie R. (2011). Financial literacy and stock market participation. Journal of Financial Economics, Vol. 101, No. 2, pp. 449-472.

- Vieira K. M., de Oliveira M. O. R., Kunkel F. I. R. (2016). The credit card use and debt: is there a trade-off between compulsive buying and ill-being perception? Journal of Behavioral and Experimental Finance, Vol. 10, No. C, pp. 75-87.

- Vissing-Jorgensen A. (2003). Perspectives on behavioral finance: does "irrationality" disappear with wealth? Evidence from Expectations and Actions. NBER macroeconomics Annual, Vol. 18, pp. 139-194.

- Weber J., Meyer S., Loos B., Hackethal A. (2014). Which investment behaviors really matter for individual investors. Working Paper. Available at https://www.scribd.com/document/207047989/SSRN-id2381435

- WEF, World Economic Forum, (2017). We'll Live to 100. How can we afford it? World Economic Forum White Paper. Available at: https://www.weforum.org/whitepapers/we-II-live-to-100-how-can-weafford-it

- Zinman J. (2010). Restricting consumer credit access: household survey evidence on effects around the Oregon rate cap. Journal of banking \& Finance, Vol. 34, No, 3, pp. 546-556.

- Zinman J. (2014). Consumer credit: too much or too little (or just right)? Journal of Legal Studies, Vol. 43, No. S2, pp. S209-S237.

- Zinman J. (2015). Household debt: facts, puzzles, theories, and policies. Annual Review of Economics, Vol. 7, No. 1, pp. 251-276.

- Zinman J., Zitzewitz E. (2016). Wintertime for deceptive advertising? American Economic Journal: Applied Economics, Vol. 8, No. 1, pp. 177-192.

- Zocchi P. (2013). Why do Italian households prefer adjustable rate mortgages? Journal of European Real Este Research, Vol. 6, No. 1, pp. 90-110. 